\title{
Blends of diesel and biodiesel of cooking oil waste and moringa (Moringa oleifera Lam): kinetic and thermal analysis and monitoring during storage
}

\author{
Tathilene Bezerra Mota Gomes Arruda ${ }^{2}$ (D) Manoel Barbosa Dantas ${ }^{1} \cdot$ \\ Kelvin Costa de Araújo ${ }^{1}$ - Francisco Eduardo Arruda Rodrigues ${ }^{3}$. \\ Nágila Maria Pontes Silva Ricardo ${ }^{2} \cdot$ Samuel Guedes Bitu $^{1}$
}

Received: 31 October 2016/Accepted: 21 March 2017/Published online: 27 March 2017

(c) The Author(s) 2017. This article is an open access publication

\begin{abstract}
This research reports the use of cooking oil waste and moringa biodiesel and their blends into mineral diesel and the influence of the storage conditions. The behavior of the blend between moringa and cooking oil waste and biodiesel were evaluated through thermogravimetric analysis and the data were used in the determination of the kinetic parameters of the blends as activation energy and pre-exponential factor and the values found were similar to reported in literature for others samples of biodiesel. The quality of the blend between biodiesel and diesel and the influence of storage conditions were evaluated through the determination of the acid value of the samples. The acid value for the samples that contained mineral diesel was virtually constant. The acid values of the samples of biodiesel were not in accordance with Brazilian legislation, but did not affect the quality of the blend with mineral diesel. The average values of activation energy for waste cooking oil and moringa biodiesel were $70.04 \pm 2.99$ and $53.80 \pm 6.83 \mathrm{~kJ} \mathrm{~mol}^{-1}$, respectively.
\end{abstract}

Keywords Biodiesel · Diesel - Kinetic parameter . Storage $\cdot$ Moringa

Tathilene Bezerra Mota Gomes Arruda tathilene@gmail.com

1 Instituto Federal da Paraíba-IFPB, Campus Sousa, Sousa, PB 58805-345, Brazil

2 Universidade Federal do Ceará-UFC, Campus do Pici, Fortaleza, CE 60455-760, Brazil

3 Instituto Federal do Ceará-IFCE, Campus Caucaia, Caucaia, CE 61609-090, Brazil

\section{Introduction}

The using of the biodiesel as energetic source shows itself as alternative instead of the utilization of non-renewable fossil fuels as the petroleum, natural gas and coal. Besides the maintenance of the carbon cycle, the utilization of the biodiesel allows reduction of the emission of pollutant substances which cause acid rain or damage to the ozone layer, proving benefic effect in the environment.

The biodiesel can be used purely (B100) or blended with the mineral diesel in motors of diesel cycle. The proportion blended with diesel is expressed by a nomenclature accepted worldwide: the $\mathrm{BX}$, where $\mathrm{X}$ is percentage of diesel added to the mineral diesel. For example, B2, B5, B20 and B50 represent concentration of 2, 5, 20 and 50\% of biodiesel in the diesel [1]. In the B5, the biodiesel is considered an additive of the diesel and in B2 the biodiesel is an additive of lubricity of the diesel. An example of advantage of the use of the biodiesel is the possibility of the blend in several proportions. After the blend, the biofuel formed keeps the standards of quality required for the fuels and can be used in motor diesel without the necessity of modifications in the engines. Nowadays, the biodiesel in Brazil is added to the diesel with 7\% proportion [2].

Example of oleaginous, the moringa (Moringaoleifera) belongs to Moringaceae family and can be found in the northeast of India, Africa, Arabia, Asia, Pacific and Caribbean Islands and South America [3, 4]. The moringa oil extraction in large scale is difficult and its use in industrial scale is not known, but a study using pilot plant of extraction of moringa oil with carbon dioxide as supercritical fluid is reported in literature [5] and this resource shows itself as alternative to the difficulty of obtaining moringa oil. There were no significant differences between the oil extracted by supercritical fluid and other conventional methods [5]. 
Researchers also report the optimization of the transesterification conditions of the moringa oil and the behavior of the biodieselblended with diesel in engines [6, 7]. Since moringa oil is non-edible and quite stable, the production of biodiesel using can be favored and this fact can be verified by the presence in the literature of several papers relating its behavior in diesel engines [7-10].

Other option for the production of biodiesel is the use of cooking oil waste due to its low cost and as solution for problem of disposal and potential contamination of the environment by these residues [11]. Studies report the action of the biodiesel prepared from cooking oil waste, and the emission of carbon dioxide [12] and its behavior observed in the engines were similar to that of the biodiesel obtained from other oleaginous resources. Pre-treatments are necessary to remove solid waste and water from the cooking oil waste. The literature reports techniques as acid transesterification, neutralization by alkali and posteriorly removed by decantation, extraction of the free fatty acid using polar liquids and distillation of the free fatty acid are for the reduction of the free fatty acid concentration [13]. Thus, the production of the biodiesel of cooking oil waste represents a sustainable and environmentally correct process, once the utilization of the cooking oil waste provides an efficient destiny instead of the expose of this oil in the nature.

Using biodiesel of distinct raw material, the objective of this present research was to evaluate the behavior of the blends between biodiesel and mineral diesel. Parameters as storage conditions were analyzed and the influence of the quality of the biodiesel on the blend was followed using thermogravimetric methods and acid number value. The methods proposed by Coats-Redfern [14] and Madhusudanan [15] were utilized for the study. These methods offer integral resolution of the equation of the Arrhenius temperature and without supposition of the model kinetic-modelfree methods. The use of thermogravimetric data in the determination of the kinetic parameters is largely used in the determination of the biofuel quality [16-19] and represents an advance in the study of biofuels: characteristics of combustion can be evaluated using motor prototypes and through this method a large quantity of fuel need to be burned. The determination of the kinetic parameters using thermogravimetric data shows low cost when compared to prototypes used for the same objective and provides the same information using a small quantity of sample in the analysis.

\section{Materials and methods}

\section{Materials}

Cooking oil waste was collected from the student restaurant of the Federal Institute of Paraíba-Campus Sousa, located in the Sousa city, Paraíba, Brazil. Heating and filtration were used as pre-treatment. The moringa fruits were collected at the Federal University of Campina GrandeCampus Cajazeiras, located in the Cajazeiras city, Paraíba, Brazil. The fruits were processed (extraction of the peanut), dried in oven at $50{ }^{\circ} \mathrm{C}$ for $24 \mathrm{~h}$ and grinded. The moringa oil extraction was conducted using Soxhlet system (Fig. 1) containing a glass balloon, condenser, heating mantle and extractor Soxhlet, solvent temperature around $67{ }^{\circ} \mathrm{C}, n$ hexane as solvent and $6 \mathrm{~h}$ of time extraction. At the end of this time, the $n$-hexane was removed using reduced pressure and the oil was collected. Other additional resources were potassium hydroxide powder $(85 \%)$ by Synth, anhydrous sodium sulfate by Vetec and ethyl alcohol (P.A.) by Synth.

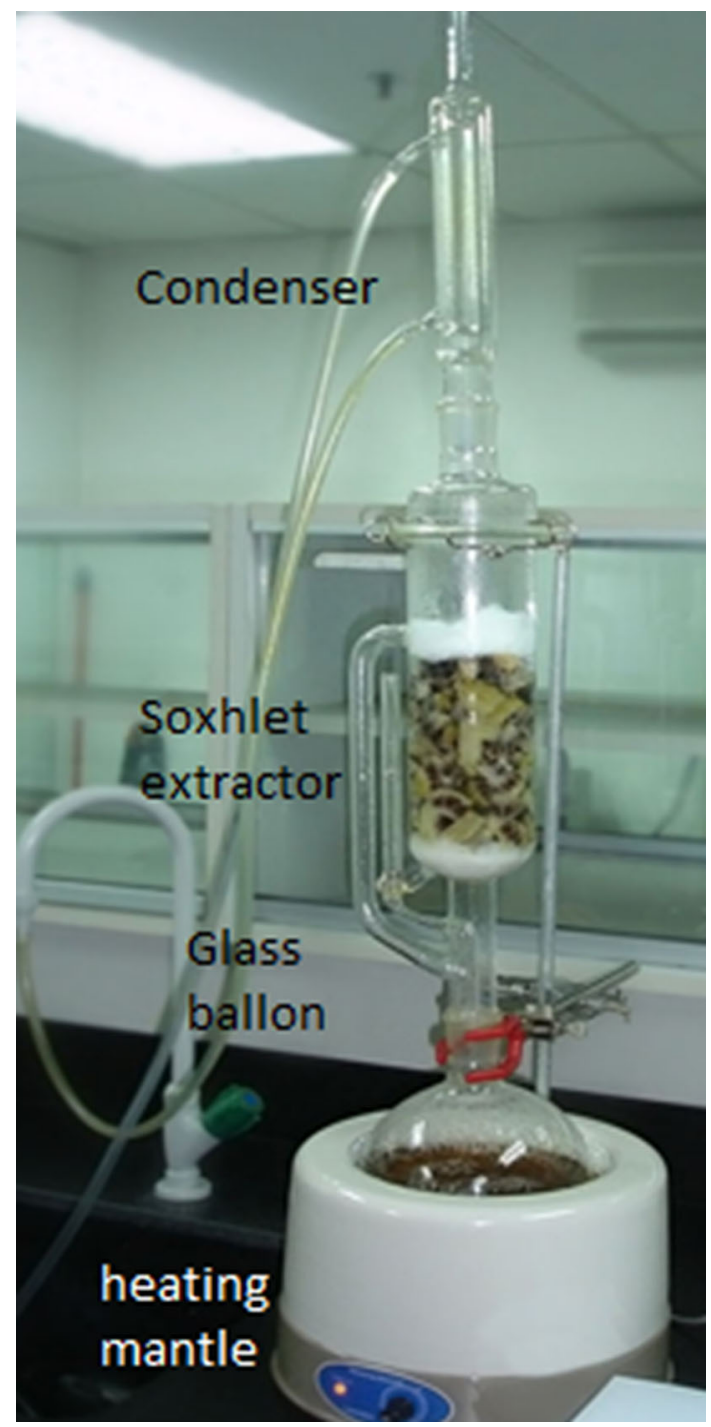

Fig. 1 Sohxlet extraction of the moringa oil (Author archive) 
Synthesis of the ethyl derivative of moringa (BEM) and cooking oil waste (BEF)

The obtaining of the ethyl biodiesel of cooking oil waste (BEF) and biodiesel of moringa (BEM) was conducted through reaction of transesterification using homogeneous alkaline catalysis. Potassium ethoxide was prepared mixing $30 \mathrm{~g}$ of ethanol and potassium hydroxide (two conditions were used: 1 and $1.5 \mathrm{~g}$ of potassium hydroxide) in bottom round glass flask. The mixture was kept under stirring until the dissolution of the potassium hydroxide in the ethyl alcohol and formation of the potassium ethoxide. Then, the solution was added to $100 \mathrm{~g}$ of the oil and the reaction system was kept under stirring and room temperature for $1 \mathrm{~h}$. The molar ratio obtained corresponds to 1:6 oil: alcohol. At the end of the time reaction, the biodiesel was separated from the glycerin in separation funnel and the biodiesel was washed until neutralization of the water and dried with anhydrous sulfate. After, the biodiesel was kept on oven at $110{ }^{\circ} \mathrm{C}$ to remove residual water.

\section{Preparation of the blends}

The blends (BFMx) of ethyl biodiesel of cooking oil waste (BEF) and ethyl biodiesel of moringa (BEM) were prepared by addition of 10 and $20 \%(\mathrm{v} / \mathrm{v})$ of BEM to BEF and named BFM10 and BFM20, respectively. The blends were prepared by addition of 10 and $20 \mathrm{ml}$ of BEF in distinct volumetric flasks of $100 \mathrm{~mL}$ and the volume was completed with BEM. Then the blend was kept under stirring for homogenization for $5 \mathrm{~min}$.

The process was similar to the blends (DBFMx) prepared by the addition of $7 \%$ of BFMx blends to the mineral diesel. $7 \mathrm{~mL}$ of BFM10 and BFM20 was added to distinct volumetric flasks of $100 \mathrm{~mL}$ and the volume was completed with mineral diesel. The blends were homogenized by stirring them for $5 \mathrm{~min}$. The blends were named DBFM10(7) and DBFM20(7), respectively. It was used appropriate glassworks in the preparation of the volumetric proportions (volumetric flask, pipette and graduate beaker).

\section{Thermal and kinetic analysis of the biodiesels and the blends}

The samples were submitted to thermogravimetric analysis in equipment model Q50 V20 of the TA Instruments ${ }^{\circledR}$, constant flow of synthetic air and constant heating rate until $600{ }^{\circ} \mathrm{C}$ of maximum temperature. Three heating rates were applied to this experiment $\left(10,20\right.$ and $\left.30{ }^{\circ} \mathrm{C} \min ^{-1}\right)$. The technique consists in gradual and constant heating of the sample and determines the mass degradation during the process of heating. The values of mass degradation versus heating temperature were obtained and used in the determination of the kinetic parameters. For the research, two methods were used: Coats-Redfern [14] and Madhusudanan [15]. These methods find several applications in the analysis of biofuel as well [16, 22-26].

For a non-isothermal process, the mass variation in presence of a programed temperature variation is utilized for the kinetic calculus as observed in Eq. (1):

$\frac{\mathrm{d} \alpha}{\mathrm{d} t}=k(T) f(\alpha)$,

where $\alpha$ is correlated to a mass conversion of the reaction and $k(T)$ is the reaction velocity. The reaction velocity $k(T)$ can be substituted by equation Arrhenius (Eq. 2) and the heating rate (Eq. 3) allows the redefinition of the Eq. (1) like temperature function and not time function:

$k(T)=A e^{\frac{-E}{R T}}$,
$\frac{\mathrm{d} T}{\mathrm{~d} t}=\beta$.

By the combination of Eqs. (1) and (2) and subsequent integration, Eq. (4) is obtained, where $g(\alpha)$ is a function that models the reaction mechanism:

$g(\alpha)=\int \frac{\mathrm{d}(\alpha)}{f(\alpha)}=\frac{A}{\beta} \int e^{\frac{-E}{R T}} \mathrm{~d} T$.

The mathematical treatment for the resolution of the integral exponential constitutes different methods for the kinetic parameters determination. This integral is known as Arrhenius integral temperature $p(x)$. The theory was developed for solid degradation and several authors apply it to liquid fuel combustion [13-16]. In this case, the parameters were called apparent.

\section{Storage tests}

The storage tests were conducted in oven and room temperatures. For the tests in oven, the samples were stored in oven at $60 \pm 2{ }^{\circ} \mathrm{C}$ for 8 days. The samples were monitored through determination of the acid number [20]. For the test in room temperature, the samples were stored in translucent glass containers under two different conditions: exposed and no exposed to the visible light at room temperature for 30 days. The samples also were monitored through determination of the acid number [20] each 15 days.

\section{Results and discussion}

The yield of the extraction of the moringa oil was $33.8 \%$. This yield was satisfactory when compared to other oleaginous that are major sources for the production of biodiesel in Brazil, as the soy and cotton with oil yield around $18-20 \%$ [21]. 
Table 1 Conversion of the BEF and BEM

\begin{tabular}{lll}
\hline & $1.0 \%$ of catalyst & $1.5 \%$ of catalyst \\
\hline $\begin{array}{l}\text { Conversion of } \\
\text { BEF }(\%)\end{array}$ & $63.44 \pm 1.4$ & $82.20 \pm 1.1$ \\
$\begin{array}{c}\text { Conversion of } \\
\text { BEM }(\%)\end{array}$ & Saponification has occurred & $79.30 \pm 0.6$ \\
\hline
\end{tabular}

The yield of the transesterification reaction was improved with the increase of the quantity of catalyst. Using $1 \%$ of catalyst, in the transesterification reaction of the moringa oil occurred saponification and the yield of the reaction was prejudiced. With the increase of the catalyst for $1.5 \%$, the yield of the transesterification reaction of the moringa oil was $79.30 \pm 0.6 \%$. For the cooking oil waste, the yield increased around $30 \%$ with the increase of the catalyst concentration. The values of yield were compiled on Table 1.

Figue 2 corresponds to the thermogravimetric curves (TG) of the samples in oxidative atmosphere. The TG showed decomposition in one-step correlated to the combustion of the esters. The onset temperature of the thermal event for the samples was higher than $100{ }^{\circ} \mathrm{C}$ and the hypothesis of an eventual presence of water was excluded. The behavior of the TG curves was similar to others reported in literature for biodiesel with same quality [16, 18, 19, 22].

The initial temperature of degradation (Tonset) of BEM is around $100{ }^{\circ} \mathrm{C}$ higher than $\mathrm{BEF}$, demonstrating the excellent thermal stability of moringa biodiesel. On the other hand, the thermal behavior of the cooking oil waste biodiesel can be explained by the thermal stress that the oil was submitted before the use as raw material for the biodiesel production. The thermal behavior of the samples was not affected by the increase of the heating rate. The addition of moringa biodiesel to the cooking oil waste biodiesel did not affect significantly the thermogravimetric behavior for the proportions evaluated in this research. The intervals of temperature and peak temperature for the only thermal event observed in TG curves were compiled on the Table 2 .

The kinetic analysis was made using the methods proposed by Coats-Redfern and Madhusudanan. These methods consist of a mathematic treatment of the

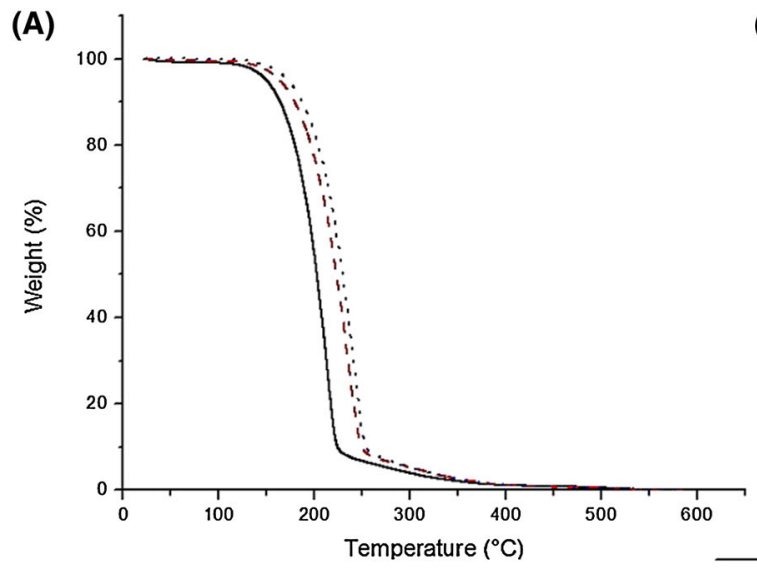

(B)
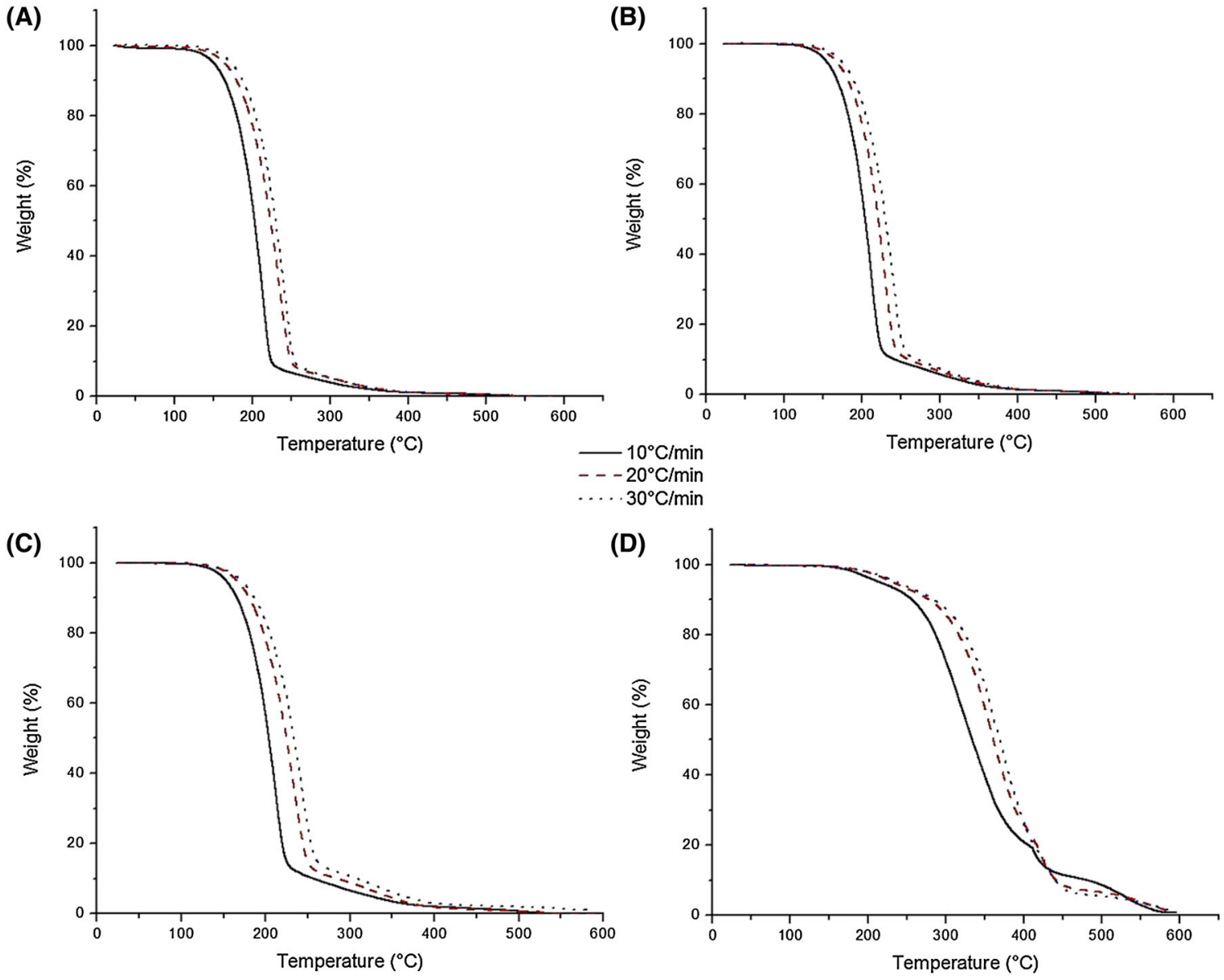

Fig. 2 Thermogravimetric curves for a BEF, b BFM10, c BFM20 and d BEM 
Table 2 Onset and peak temperatures for the biodiesel samples and the blends

\begin{tabular}{|c|c|c|c|c|c|c|c|c|}
\hline & \multicolumn{2}{|l|}{ BEF } & \multicolumn{2}{|l|}{ BEM } & \multicolumn{2}{|l|}{ BFM10 } & \multicolumn{2}{|l|}{ BFM20 } \\
\hline & $T_{\text {onset }}\left({ }^{\circ} \mathrm{C}\right)$ & $T_{\text {peak }}\left({ }^{\circ} \mathrm{C}\right)$ & $T_{\text {onset }}\left({ }^{\circ} \mathrm{C}\right)$ & $T_{\text {peak }}\left({ }^{\circ} \mathrm{C}\right)$ & $T_{\text {onset }}\left({ }^{\circ} \mathrm{C}\right)$ & $T_{\text {peak }}\left({ }^{\circ} \mathrm{C}\right)$ & $T_{\text {onset }}\left({ }^{\circ} \mathrm{C}\right)$ & $T_{\text {peak }}\left({ }^{\circ} \mathrm{C}\right)$ \\
\hline $10^{\circ} \mathrm{C} \min ^{-1}$ & 115.00 & 213.35 & 236.60 & 326.35 & 127.76 & 236.69 & 134.10 & 240.69 \\
\hline $20^{\circ} \mathrm{C} \min ^{-1}$ & 117.00 & 213.25 & 246.97 & 356.20 & 121.40 & 230.33 & 129.88 & 240.94 \\
\hline $30^{\circ} \mathrm{C} \min ^{-1}$ & 117.00 & 210.99 & 257.69 & 366.57 & 123.32 & 232.05 & 129.26 & 240.50 \\
\hline
\end{tabular}

Table 3 Kinetic parameter of the sample using Coats-Redfern and Madhusudanan methods

\begin{tabular}{|c|c|c|c|c|c|c|c|}
\hline & & $\begin{array}{l}\text { Coats-Redfern } \\
E_{\mathrm{a}}\left(\mathrm{kJ} \mathrm{mol}^{-1}\right)\end{array}$ & $A\left(\mathrm{~s}^{-1}\right)$ & $R^{2}$ & $\begin{array}{l}\text { Madhusudanan } \\
E_{\mathrm{a}}\left(\mathrm{kJ} \mathrm{mol}^{-1}\right)\end{array}$ & $A\left(\mathrm{~s}^{-1}\right)$ & $R^{2}$ \\
\hline \multirow[t]{3}{*}{ BEF } & $10{ }^{\circ} \mathrm{C} \min ^{-1}$ & 71.98 & $5.68 \times 10^{-2}$ & 0.9994 & 72.28 & $4.96 \times 10^{6}$ & 0.9994 \\
\hline & $20{ }^{\circ} \mathrm{C} \min ^{-1}$ & 66.03 & $6.49 \times 10^{-3}$ & 0.9995 & 66.34 & $2.79 \times 10^{6}$ & 0.9995 \\
\hline & $30{ }^{\circ} \mathrm{C} \min ^{-1}$ & 71.64 & $1.88 \times 10^{-2}$ & 0.9995 & 71.65 & $1.63 \times 10^{6}$ & 0.9995 \\
\hline \multirow[t]{3}{*}{ BEM } & $10{ }^{\circ} \mathrm{C} \min ^{-1}$ & 45.30 & $2.42 \times 10^{-6}$ & 0.9618 & 45.70 & $2.37 \times 10^{3}$ & 0.9626 \\
\hline & $20^{\circ} \mathrm{C} \min ^{-1}$ & 55.17 & $8.38 \times 10^{-6}$ & 0.985 & 55.57 & $4.50 \times 10^{2}$ & 0.9853 \\
\hline & $30{ }^{\circ} \mathrm{C} \min ^{-1}$ & 60.32 & $1.80 \times 10^{-5}$ & 0.9883 & 60.73 & $1.15 \times 10^{3}$ & 0.9985 \\
\hline \multirow[t]{3}{*}{ BFM10 } & $10^{\circ} \mathrm{C} \min ^{-1}$ & 75.08 & 0.11 & 0.9997 & 75.38 & $1.05 \times 10^{7}$ & 0.9997 \\
\hline & $20{ }^{\circ} \mathrm{C} \min ^{-1}$ & 74.09 & $4.5 \times 10^{-2}$ & 0.9997 & 74.40 & $4.16 \times 10^{6}$ & 0.9996 \\
\hline & $30^{\circ} \mathrm{C} \min ^{-1}$ & 71.88 & $1.9 \times 10^{-2}$ & 0.9996 & 72.20 & $1.7 \times 10^{6}$ & 0.9996 \\
\hline \multirow[t]{3}{*}{ BFM20 } & $10{ }^{\circ} \mathrm{C} \min ^{-1}$ & 74.42 & $4.4 \times 10^{-2}$ & 0.9986 & 71.73 & $3.14 \times 10^{5}$ & 0.9986 \\
\hline & $20{ }^{\circ} \mathrm{C} \min ^{-1}$ & 64.30 & $4.09 \times 10^{-3}$ & 0.998 & 64.61 & $2.88 \times 10^{5}$ & 0.998 \\
\hline & $30{ }^{\circ} \mathrm{C} \min ^{-1}$ & 62.13 & $1.94 \times 10^{-3}$ & 0.9971 & 62.45 & $1.28 \times 10^{5}$ & 0.9971 \\
\hline
\end{tabular}

Arrhenius equation and are classified as model-free methods. In the treatment of the thermogravimetric data, several kinetic models are tested and the model that fits the data is chosen for the determination of the kinetic parameters. In other words, the model that provides linear correlation closest to the unity is the best model for the analysis of the parameters. The apparent kinetic model found for the samples was the same, $R^{2}$ model, kinetic based in a bidimensional geometric model and reaction in limitrofe phase and cylindrical symmetry. The kinetic parameters of the biodiesel of cooking oil waste were not affected by the addition of the moringa biodiesel. The apparent activation energy is correlated to delay in the combustion of the fuel in the motor diesel. Thus, biodiesel activation energy higher or lower than diesel activation energy will produce an incomplete combustion in the chamber of the motor. Once the average values for the apparent activation energy $\left(70.04 \pm 2.99 \mathrm{~kJ} \mathrm{~mol}^{-1}\right.$ for BEF, $53.80 \pm 6.83 \mathrm{~kJ} \mathrm{~mol}^{-1}$ for BEM, $73.84 \pm 1.47 \mathrm{~kJ} \mathrm{~mol}^{-1}$ for BFM10 and $66.61 \pm 5.17 \mathrm{~kJ} \mathrm{~mol}^{-1}$ for BFM20.) were similar to the reported for mineral fuels [23], a complete combustion in a motor diesel, when blended with mineral diesel, is expected. These values were also similar to those reported for other kinds of biodiesel [16, 22] (Table 3).

The results of the test storage showed that the conditions and time of storage influenced directly the values of the acid number of the samples, in others words; the quality of the fuel is directly affected by the conditions of storage. The blends with higher percentage of BEF were most affected by the conditions of storage. This behavior occurs due to the low stability of oxidation of the BEF. On the other hand, the acid number was constant for the blends with mineral diesel, a behavior explained by the high stability of the mineral diesel. All the blends containing mineral diesel were in accordance with Brazilian Legislation for blends between biodiesel and mineral diesel, including the blend that contains BEF, the most unstable biodiesel of the experiment [2]. In other words the high stability of the diesel kept the quality of the blend with biodiesel in the proportion evaluated. The BEM sample was in accordance with the value allowed for the acid number in storage without visible light exposure. The other samples that did not contain diesel were outside the range established. The relation between the time and type of exposure was showed on the Figs. 3, 4 and 5. 


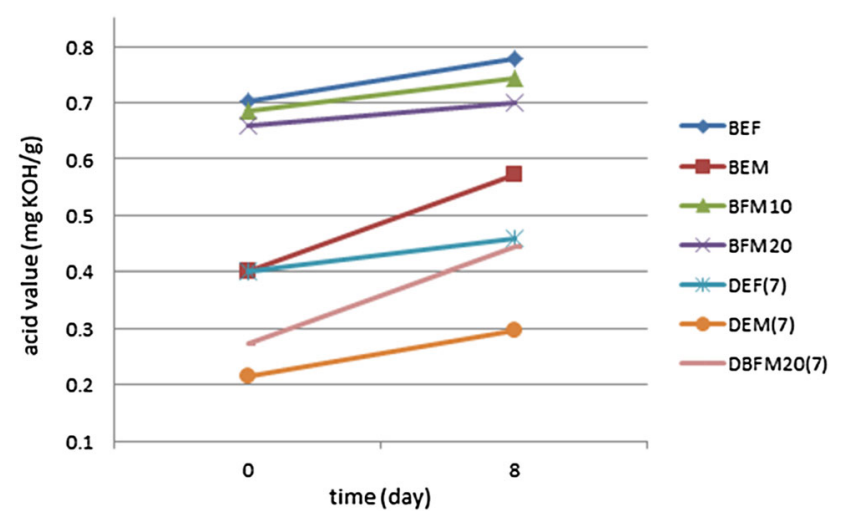

Fig. 3 Acid value for the samples when stored in oven

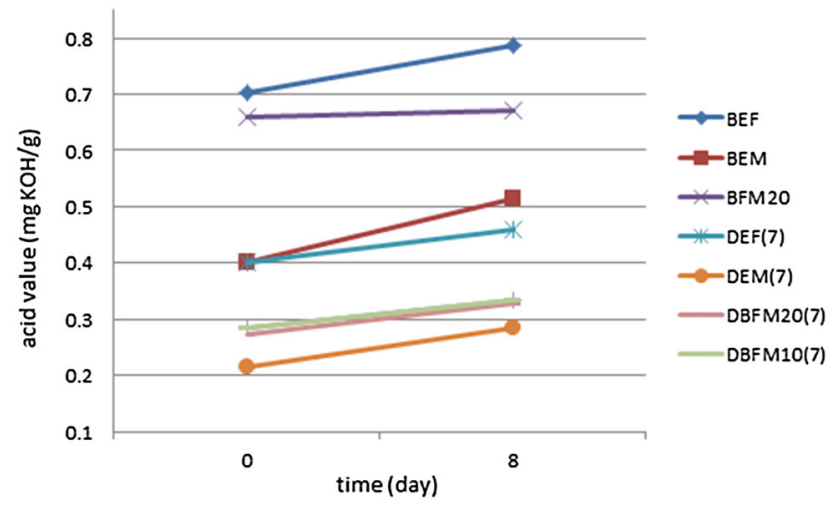

Fig. 4 Acid value for the samples when storage is exposed on visible light

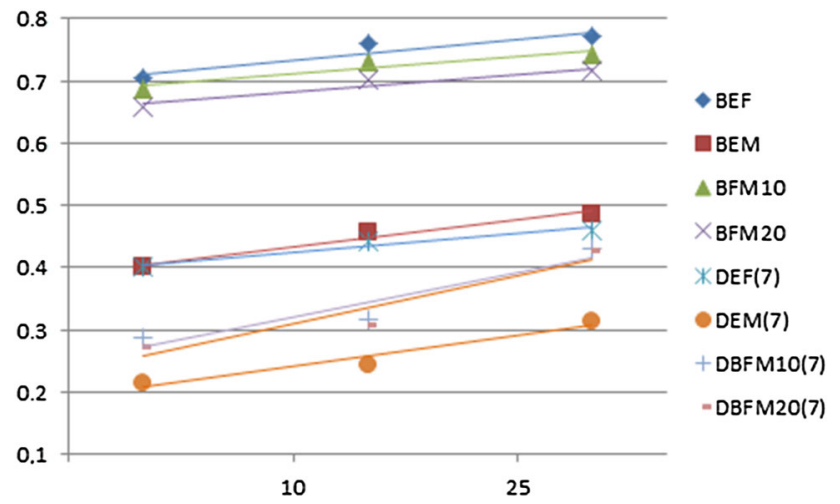

Fig. 5 Acid value for the samples when storage is not exposed on visible light

\section{Conclusions}

As observed, the moringa oil and cooking oil waste represent the extremes in the production of biodiesel: biodiesel of cooking oil waste was not as stable as the biodiesel of moringa oil. But the results showed low influence of the biodiesel in the quality of the diesel blend. At the best of our efforts in research, the behavior of the biofuels and blends under specific storage conditions is first time reported. The thermogravimetric analysis of the blends BFM10 and BFM20 showed thermal behavior similar to that observed in BEF, and BEM showed the best thermal stability when compared to BEF once the onset temperature of degradation of BEM was around $100{ }^{\circ} \mathrm{C}$ higher than BEF. The possibility of presence of water was excluded in all the samples once the onset temperature for the only thermal event observed in TG curves was higher than $100{ }^{\circ} \mathrm{C}$. The increase of the heating rate did not result in significant alterations in the thermal behavior of the samples. The utilization of thermogravimetric data allowed the determination of the apparent kinetic parameters as the activation energy and pre exponential factor. As observed in the TG curves, the values of the activation energy for BFM10 and BFM20 were similar to those observed in $\mathrm{BEF}$, once the quantity of BEF was higher in the blend. The pseudo-kinetic suggested by the applied methods was the same for all the samples and corresponded to $R^{2}$ model. The average values of the activation energy for the biodiesel samples and their blends were close to values reported in literature for mineral fuels [20] and imply a low time delay in the combustion when blended with mineral fuel. The conditions and the time of the storage caused significant and crescent variations in the acid number of the samples that contain biodiesel. This behavior was observed mainly in the samples with large percentage of BEF once the cooking oil waste biodiesel has the lowest thermal stability between the biodiesels evaluated. When appropriately conditioned, in other words, in room temperature and non-exposed to visible light, the moringa biodiesel kept its acid number under allowed value for biodiesel samples. On other hand, the blends containing mineral diesel showed acid number virtually constant once the mineral diesel has high oxidation stability. Thus, the quality of the biodiesel did not affect the quality of the diesel when blended in the proportion determined by Brazilian legislation and the evaluating of the storage conditions were more necessary in the samples of biodiesel.

Acknowledgements The authors thank Federal Institute of Education, Science and Technology of Paraíba-Campus Sousa (IFPb), the Laboratory of Chemistry of IFPb, Federal University of Paraíba $(\mathrm{UFPb})$ and the Laboratory of Fuels and Materials (LACOM), and the Federal University of Ceará (UFC) for the equipment and materials and CNPq and CAPES for the financial support.

Open Access This article is distributed under the terms of the Creative Commons Attribution 4.0 International License (http://creative commons.org/licenses/by/4.0/), which permits unrestricted use, distribution, and reproduction in any medium, provided you give appropriate credit to the original author(s) and the source, provide a link to the Creative Commons license, and indicate if changes were made. 


\section{References}

1. Datta, A., Mandal, B.K.: A comprehensive review of biodiesel as an alternative fuel for compression ignition engine. Renew. Sustain. Energy Ver. 57, 799-821 (2016). doi:10.1016/j.rser. 2015.12.170

2. ANP-Agência Nacional do Petróleo, Gás Natural e Biocombustíveis. Resolução ${ }^{\circ}$ 45-25.8.2014

3. Morton, J.F.: The horseradish tree, moringa pterygosperma (Moringaceae) — a boon to arid land? Econ. Bot. 45(3), 318-333 (1991). doi:10.1007/BF02887070

4. Rashid, U.F., Anwar, F., Moser, B.R., Knothe, G.: Moringa oleifera oil: a possible source of biodiesel. Bioresour. Technol. 99, 8175-8179 (2008). doi:10.1016/j.biortech.2008.03.066

5. Ruttarattanamongkol, K., Siebenhandl-Ehn, S., Schreiner, M., Petrasch, A.M.: Pilot-scale supercritical carbon dioxide extraction, physico-chemical properties and profile characterization of Moringa oleifera seed oil in comparison with traditional extraction methods. Ind. Crop. Prod. 58, 68-77 (2014). doi:10.1016/j. indcrop.2014.03.020

6. Kafuku, G., Mbarawa, M.: Alkaline catalyzed biodiesel production from Moringa oleifera oil with optimized production parameters. Appl. Energy 87, 2561-2565 (2010). doi:10.1016/j. apenergy.2010.02.026

7. Mofijur, M., Masjuki, H.H., Atabani, A.E., Arbab, M.I., Cheng, S.F., Gouk, S.W.: Properties and use of Moringa oleifera biodiesel and diesel fuel blends in a multi-cylinder diesel engine. Energy Convers. Manag. 82, 169-176 (2014). doi:10.1016/j. enconman.2014.02.073

8. Mofijur, M., Masjuki, H.H., Kalam, M.A., Atabani, A.E., Fattah Rizwanul, I.M., Mobarak, H.M.: Comparative evaluation of performance and emission characteristics of Moringa oleifera and palm oil based biodiesel in a diesel engine. Ind. Crop. Prod. 53, 78-84 (2014). doi:10.1016/j.indcrop.2013.12.011

9. Rashed, M.M., Kalam, M.A., Masjuski, H.H., Mofijur, M., Rasul, M.G., Zilkifli, N.W.M.: Performance and emission characteristics of a diesel engine fueled with palm, jatropha and moringa oil methyl esters. Ind. Crop. Prod. 79, 70-76 (2016). doi:10.1016/j. indcrop.2015.10.046

10. Rahman, M.M., Hassan, M.H., Kalam, M.A., Atabani, A.E., Memon, L.A., Rahman, S.M.A.: Performance and emission analysis of Jatropha curcas and Moringa oleifera methyl ester fuel blends in a multi cylinder diesel engine. J. Clean. Prod. 65, 304-310 (2014). doi:10.1016/j.jclepro.2013.08.034

11. Xue, Y., Zhao, W., Ma, P., Zhao, Z., Xu, G., Yang, C., Chen, H., Lin, H., Han, S.: Ternary blends of biodiesel with petro-diesel and diesel from direct coal liquefaction for improving the cold flow points properties of waste cooking oil biodiesel. Fuel 177, 46-52 (2016). doi:10.1016/j.fuel.2016.02.087

12. Xue, J.: Combustion characteristics, engine performances and emissions of waste edible oil biodiesel in diesel engine. Renew. Sustain. Energy Rev. 23, 350-365 (2013). doi:10.1016/j.rser. 2013.02.039
13. Yaakob, Z., Mohhamad, M., Alherbawi, M., Alam, Z., Sophian, K.: Overview of the production of biodiesel from waste cooking oil. Renew. Sustain. Energy Rev. 18, 184-193 (2013). doi:10. 1016/j.rser.2012.10.016

14. Coats, A.W., Redfern, N.J.P.: Thermogravimetric analysis-a review. Analyst 88, 906-924 (1963). doi:10.1038/1731011b0

15. Krishnan, K., Ninan, K.N., Madhusudanan, P.M.: Equations or the rapid evaluation of general temperature integrals in nonisothermal kinetic analysis. Termochim Acta 125, 111-124 (1988). doi:10.1016/0040-6031(88)87216-2

16. Arruda, T.B.M.G., Rodrigues, F.E.A., Arruda, D.T.D., Ricardo, N.M.P.S., Dantas, M.B., de Araújo, K.C.: Chromatography, spectroscopy and thermal analysis of oil and biodiesel of sesame (Sesamum indicum) — an alternative for the Brazilian Northeast. Ind. Crop. Prod. 91, 264-271 (2016). doi:10.1016/j.indcrop.2016. 07.029

17. Kok, M.V.: Thermal behavior and kinetics of crude oils at low heating rates by differential scanning calorimeter. Fuel Process. Technol. 96, 123-127 (2012). doi:10.1016/j.fuproc.2011.12.027

18. Li, H., Niu, S., Lu, C., Sheng, S.: Comparative evaluation of thermal degradation for biodiesels derived from various feedstocks through transesterification. Energy Convers. Manag. 98, 81-88 (2015). doi:10.1016/j.enconman.2015.03.097

19. Dalpasquale, M., Lopes, M.C., Anaissi, F.J.: Análise térmica aplicada na determinação da energia de ativação. Um experimento para o laboratório didático de físico-química. Orbital Eletron. J. Chem. 5(4), 271-278 (2013)

20. Instituto Adolfo Lutz: Normas analíticas do Instituto Adolfo Lutz: métodos químicos e físicos para análise de alimentos, 4th edn. Instituto Adolfo Lutz, Brasília (2005)

21. Moretto, E., Fett, R.: Tecnologia de óleos e gorduras vegetais na indústria de alimentos, 1st edn. Livraria Varela, São Paulo (1998)

22. Dantas, M.B., Conceição, M.M., Fernandes Jr., V.J., Santos, N.A., Rosenhaim, R., Marques, A.L.B., Santos, I.M.G., Souza, A.G.: Thermal and kinetic study of corn biodiesel obtained by the metanol and etanol routes. J. Therm. Anal. Calorim. 87, 835-839 (2007). doi:10.1007/s10973-006-7780-2

23. Leiva, C.R.M., Crnkovic, P.M., dos Santos, A.M.: O emprego da termogravimetria para determinar a energia de ativação do processo de combustão de óleos combustíveis. Quim. Nova 29(5), 940-946 (2006)

24. Maurya, R., Ghosh, T., Saravaia, H., Paliwal, C., Ghosh, A., Mishra, S.: Non-isothermal pyrolysis of de-oiled microalga biomass: kinetics and evolved gas analysis. Bioresour. Technol. 221, 251-261 (2016). doi:10.1016/j.biortech.2016.09.022

25. Chen, J., Fan, X., Jiang, B., Mu, L., Yao, P., Yin, H., Song, X.: Pyrolysis of oil-plant wastes in a TGA and a fixed-bed reactor: thermochemical behaviors, kinetics and products characterization. Bioresour. Technol. 192, 592-602 (2015). doi:10.1016/j. biortech.2015.05.108

26. Gao, W., Chen, K., Xiang, Z., Yang, F., Zeng, J., Li, J., Yang, R., Rao, G., Tao, H.: Kinetic study on pyrolysis of tobacco residues from the cigarette industry. Ind. Crop. Prod. 44, 152-157 (2013). doi:10.1016/j.indcrop.2012.10.032 